\title{
Serosurveillance of foot-and-mouth disease virus in selected livestock-wildlife interface areas of Tanzania
}

\author{
Authors: \\ Mathias Mkama ${ }^{1}$ \\ Christopher J. Kasanga ${ }^{2}$ \\ Raphael Sallu ${ }^{1}$ \\ Ezekia Ranga $^{3}$ \\ Mmeta Yongolo ${ }^{1}$ \\ Misheck Mulumba ${ }^{4}$ \\ Mark Rweyemamu² \\ Philemon Wambura² \\ Affiliations: \\ ${ }^{1}$ Tanzania Veterinary \\ Laboratory Agency, Tanzania \\ ${ }^{2}$ Southern African Centre \\ for Infectious Diseases \\ Surveillance, Sokoine \\ University of Agriculture, \\ Tanzania \\ ${ }^{3}$ Ministry of Livestock \\ Development and Fisheries, \\ Tanzania

\section{${ }^{4}$ Southern African \\ Development Community \\ Secretariat, Botswana} \\ Correspondence to: \\ Mathias Mkama \\ Email: \\ mkamamm@gmail.com \\ Postal address: \\ PO Box 9254, Dar es Salaam, \\ Tanzania \\ How to cite this article: \\ Mkama, M., Kasanga, C.J., \\ Sallu, R., Ranga, E., Yongolo, \\ M., Mulumba, M. et al., \\ 2014, 'Serosurveillance of \\ foot-and-mouth disease virus \\ in selected livestock-wildlife \\ interface areas of Tanzania', \\ Onderstepoort Journal of \\ Veterinary Research 81(2), \\ Art. \#718, 4 pages. \\ http://dx.doi.org/10.4102/ \\ ojvr.v81i2.718
}

Read online:

回: Scan this QR

code with your

smart phone or

mobile device

to read online.
Foot-and-mouth disease (FMD) is caused by a virus of the genus Aphthorvirus of the family Picornaviridae. There is great scientific need for determining the transmission dynamics of FMD virus (FMDV) by drawing more attention to the livestock-wildlife interface areas. A variety of literature suggests that buffalo could serve as reservoir of FMDV in wildlife and cattle. However, many FMDV research studies conducted on experimentally infected cattle as carriers and groups of animal highly susceptible to FMDV (i.e. bovine calves) have shown lower chances of transmission of the virus between carriers and the susceptible groups. These findings underscore the importance of continued research on the role played by carrier animals on FMDV transmission dynamics under natural conditions. The aim of this research study was to determine FMDV infection status among buffalo and cattle herds in selected livestock-wildlife interface areas. The sampled areas included Mikumi, Mkomazi and Ruaha national parks, where a total of 330 buffalo and bovine sera samples were collected. Laboratory analysis of the samples was done through the NSP ELISA technique using the PrioCHECK ${ }^{\circledR}$ FMDV NS Kit for detection of antibodies directed against 3ABC non-structural proteins and confirming natural infections. Results showed that $76.3 \%$ of tested sera samples were positive for FMDV. However, serotyping of NSP ELISA seroreactors with LPBE is yet to be done. This information is important for further epidemiological studies towards developing effective FMD control strategies.

\section{Introduction}

Foot-and-mouth disease (FMD) is a highly contagious disease of cloven-hoofed (even-toed) animals, for example cattle, swine, buffalo, sheep and goats (Alexandersen, Zhang \& Donaldson 2002). It is a viral disease caused by the FMD virus (FMDV). The latter is said to be the first animal pathogen identified as a virus by Loeffler and Frosch in 1898 (Brown 2003). FMDV belongs to the genus Aphthorvirus of the family Picornaviridae. Characteristically FMDV is a single-stranded positive sense RNA genome surrounded by an icosahedral capsid composed of 60 copies each of four structural proteins (VP1-4). There are seven serotypes of FMDV named O, A, C, SAT1, SAT2, SAT3 and Asian1 (Donaldson, Kitching \& Barnett 1996). However, infection with any one serotype does not confer immunity against another and within serotypes many strains can be identified by biochemical and immunological tests (Office International des Epizooties [OIE] 2009).

When FMDV infection occurs, antibodies directed against structural and non-structural proteins are produced (Lubroth \& Brown 1995). Conventional serological tests can only detect antibodies directed at structural FMDV proteins. This is a major challenge, especially in scenarios where both vaccinated and infected animals co-exist, because antibodies directed the capsid proteins of FMDV are induced by both inactivated viruses (from vaccines) and live viruses (from infected or carrier animals) (Frank et al. 2010). Therefore it is not possible to differentiate the origin of the antibodies using the conventional ELISA tests like LPBE and SPCE; instead ELISA tests for detection of antibodies directed at non-structural proteins (NSPs) were developed that can differentiate between vaccinated and infected animals (Mackay et al. 1997).

Tanzania covers an area of about $945000 \mathrm{~km}^{2}$ and two-thirds of the country's land resources constitute rangelands, suitable for livestock-keeping activities (Swai, Mrosso \& Masambu 2009, cited in Nyamurunda et al. 2007). Tanzania ranks third in Africa, after Sudan and Ethiopia, in terms of livestock population (MoLDF 2010). Despite the large number of livestock it has been difficult to benefit from this valuable sector due to some limiting barriers, one of which is FMD. FMD is endemic to Tanzania. It was first documented in 1927 and its first virus typed isolation was made in 1954 (Rweyemamu \& Loretu 1972). Of the six known serotypes of FMDV in Africa, four have been isolated and identified in Tanzania; these are Type A, O, SAT 1 and SAT 2 (Rweyemamu

Note: Proceedings of the 2nd One Health Conference in Africa. Jointly organised by the Southern African Centre for Infectious Disease Surveillance and the Tanzania National Institute for Medical Research, held at the Snow Crest Hotel in Arusha, Tanzania from 16th to 19th April 2013: http://www.sacids.org/kms/frontend/index.php?m=119.

Copyright: ๑ 2014. The Authors. Licensee: AOSIS OpenJournals. This work is licensed under the Creative Commons Attribution License. 
et al. 2008). Tanzania's FMDV status has a major impact on the country's livestock sector as it currently does not export live animals and animal products to lucrative European markets. The purpose of this research study was to determine the FMDV infection status among buffalo and cattle herds in selected livestock-wildlife interface areas of Tanzania.

\section{Materials and methods Study area and blood samples obtained}

The blood samples from buffalo and cattle utilised in this study were obtained from four interface areas in Tanzania that have been reported to have numerous incidents of FMD outbreaks. Tanzanian national parks are not fenced like the Southern African national parks; hence animals intermingle freely across their borders. The blood samples from buffalo and cattle were obtained from Mikumi, Katavi, Ruaha and Mkomazi national parks and surrounding cattle herds respectively. The blood samples were drawn from jugular veins using plain $4.5 \mathrm{~mL}$ Vacutainer ${ }^{\circledR}$ tubes plunged in Vacutainer ${ }^{\circledR}$ holders with an $18 \mathrm{G}$ needle.

\section{Sample handling}

The Vacutainer ${ }^{\circledR}$ tubes filled three-quarters with blood were kept upright in racks contained in a cool box with ice packs and serum was extracted within $12 \mathrm{~h}$ of sampling. The aliquots of $2.0 \mathrm{~mL}$ serum samples were also kept on ice packs during shipping and at $-20{ }^{\circ} \mathrm{C}$ for long-time storage in the laboratory awaiting analysis.

\section{Laboratory analysis}

The FMD NSP laboratory analysis was done at the Centre for Infectious Diseases and Biotechnology (CIDB) laboratory

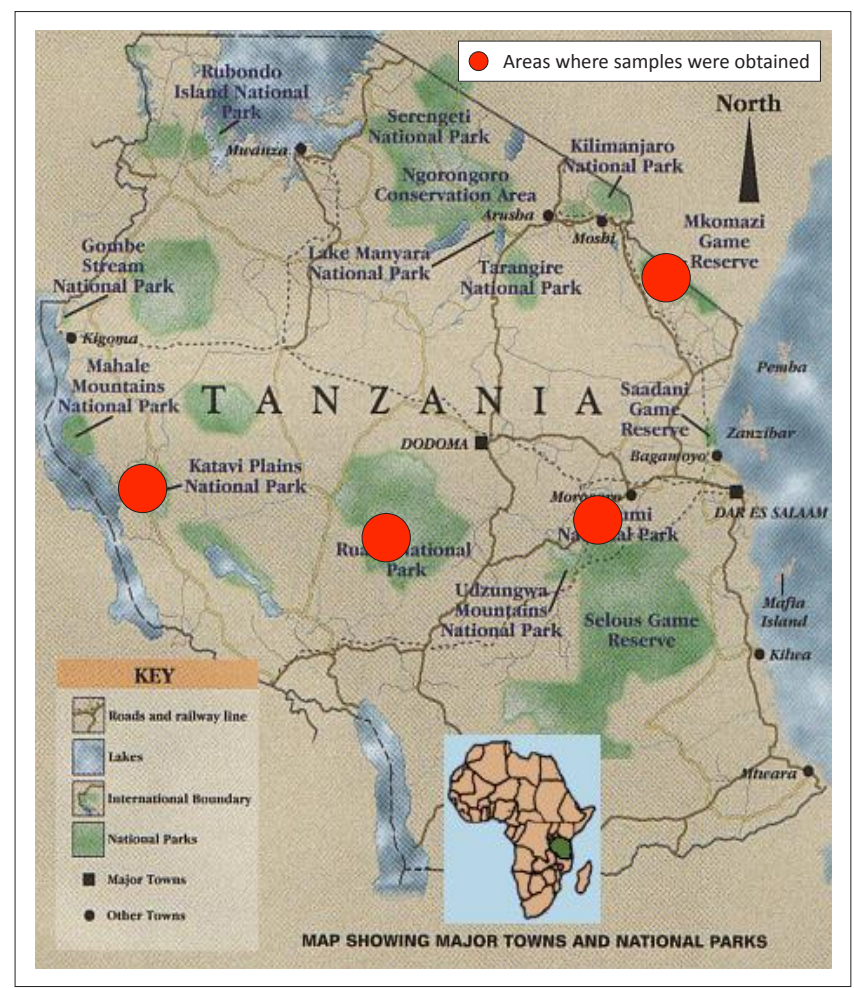

FIGURE 1: Map of Tanzania showing sampling areas. using a PrioCHECK ${ }^{\circledR}$ FMDV NS ELISA Kit (Prionics Lelystad B.V., Netherlands), batch number 7610440, manufactured in May 2012. The frozen sera samples were sorted, arranged in racks and allowed to thaw. That was followed by aliquoting $100 \mu \mathrm{L}$ from each sample into U-bottomed microplates using a $20 \mu \mathrm{L}-200 \mu \mathrm{L}$ capacity single-channel micropipette (Eppendorf, Germany). The aliquoting process followed the same plate layout as for test microplates indicated in the manufacturer's instruction manual supplied with the test kit. The working room temperature was maintained at $25^{\circ} \mathrm{C}$.

PrioCHECK ${ }^{\circledR}$ FMDV NS is a blocking ELISA that detects antibodies against the non-structural $3 \mathrm{ABC}$ proteins of all seven FMDV serotypes and it may be used to detect infection in vaccinated animals (Sorensen et al. 2005). After dispensing $20 \mu \mathrm{L}$ of test sample into test plates for incubation, the rest of the procedures were done as illustrated in the manufacturer's instruction manual.

The different colour changes on every microwell reflected different levels of antigen-antibody reactions. The values of colour changes (optical density - OD) were measured by using a Multiskan EX ELISA reader with filter set at wavelength of $450 \mathrm{~nm}$ using Ascent ${ }^{\mathrm{TM}}$ Software version 2.6.

The results were expressed in terms of percentage inhibition (PI), which was derived from the equation $\mathrm{PI}=100-\left(\mathrm{OD}_{450}\right.$ test sample/OD max) x 100. PI < 50\% meant that the sample was negative and PI $\geq 50 \%$ meant that the sample was positive.

\section{Results}

A total of 330 sera samples were analysed by NSP ELISA using the PrioCHECK ${ }^{\circledast}$ FMDV NS Kit for detection of antibodies directed against 3ABC NSP; 248 sera samples, equivalent to $76.3 \%$, tested positive. Generally, the buffalo serum samples tested demonstrated higher percentages of positive samples than the cattle serum samples from the same area; however, the opposite is true for samples obtained from the Mkomazi area (see Figures 2 and Figure 3). For buffalo serum samples tested (see Figure 2) Katavi (100\%) had the highest FMDV infection rate, followed by Ruaha (93.5\%), Mikumi (93.3\%) and Mkomazi (22.6\%).

For cattle serum samples tested (see Figure 3) there was only a slight difference in FMDV infection status between Mikumi

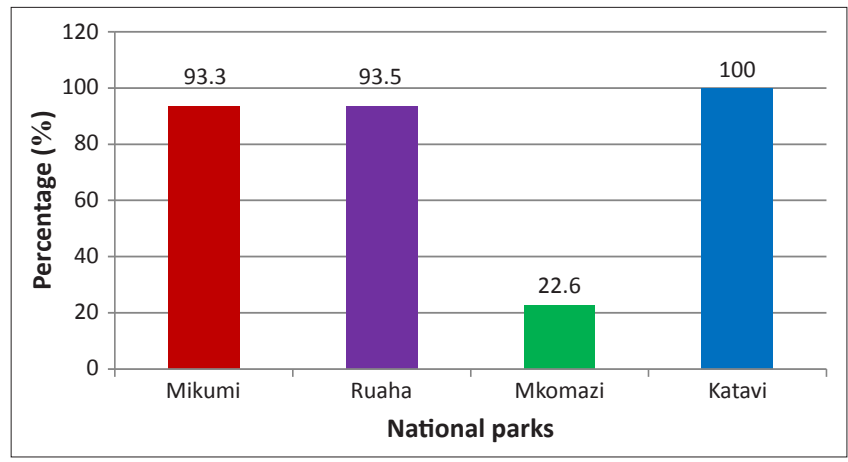

FIGURE 2: FMDV infection status in buffalos from four selected Tanzanian national parks. 
(82.9\%), Ruaha (79.3\%) and Katavi (80.3\%). Mikumi (82.9\%) had the highest percentage of positive samples and Mkomazi the lowest (58.3\%).

\section{Discussion and conclusion}

In this research study a total of 330 buffalo and cattle sera samples were analysed by NSP ELISA using the PrioCHECK ${ }^{\circledR}$ FMDV NS Kit for detection of antibodies directed against $3 \mathrm{ABC}$ non-structural proteins. A total of 248 out of 330 serum samples $(76.30 \%)$ tested positive (see Table 1$)$. The results obtained showed different FMDV infection status in terms of PI value. The highest PI values of cattle serum samples from Katavi, Ruaha, Mikumi and Mkomazi were 95.48\%, $93.56 \%, 94.24 \%$ and $94.56 \%$ respectively (see Table 1 ). Katavi presented the overall ceiling PI value $(95.48 \%)$. Katavi also presented the overall ceiling PI value (95.10\%) for buffalo serum samples analysed. The highest PI values of buffalo serum samples from Ruaha, Mikumi and Mkomazi were $94.95 \%, 94.82 \%$ and $91.65 \%$ respectively (see Table 1 ).

The high PI values could be due to two factors, namely vaccination or repeated vaccination with FMDV-specific

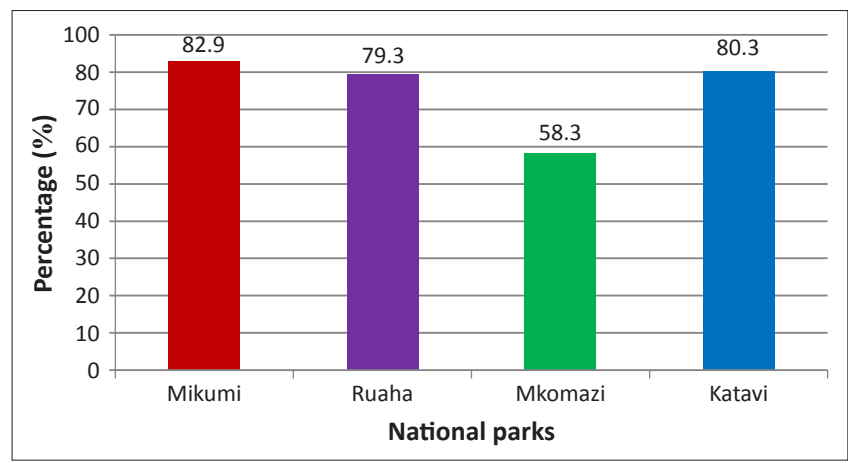

FIGURE 3: FMDV infection status in cattle herds surrounding four Tanzanian national parks.

TABLE 1: Results for NSP ELISA test using PrioCHECK ${ }^{\circledR}$ FMDV NS Kit.

\begin{tabular}{llllll}
\hline Location & Animal species & $\begin{array}{l}\text { Samples } \\
\text { tested }\end{array}$ & $\begin{array}{l}\text { Positive } \\
\text { samples }\end{array}$ & Highest PI & $\begin{array}{l}\text { Positive } \\
\text { samples (\%) }\end{array}$ \\
\hline Mikumi & Buffalo & 30 & 28 & 94.24 & 93.3 \\
& Cattle & 35 & 29 & 94.82 & 82.9 \\
\multirow{2}{*}{ Ruaha } & Buffalo & 31 & 29 & 94.95 & 93.5 \\
& Cattle & 53 & 42 & 93.56 & 79.3 \\
\multirow{2}{*}{ Mkomazi } & Buffalo & 31 & 7 & 91.65 & 22.6 \\
& Cattle & 60 & 35 & 94.56 & 58.3 \\
\multirow{2}{*}{ Katavi } & Buffalo & 29 & 29 & 95.10 & 100 \\
& Cattle & 61 & 49 & 95.48 & 80.3 \\
\hline Total & - & $\mathbf{3 3 0}$ & $\mathbf{2 4 8}$ & - & $\mathbf{7 6 . 3}$ (average) \\
\hline
\end{tabular}

(purified or unpurified) vaccines and natural infection with FMDV. The sampled herds have not been involved in any vaccination campaign against FMD for more than seven years. The same applies to buffalo herds, as vaccination for buffalos had never been practiced in Tanzanian national parks. Based on the field history and NSP ELISA results the seroreactors observed during the NSP ELISA test could be due to natural FMDV infection (OIE 2010).

The PI values obtained (see Table 2) were categorised into two groups, namely 50-69 and 70-100, based on validation criteria for PI values of weak positive and positive controls indicated in the manufacturer's instruction manual. The proportion of positive samples with PI values in the range 70-100 appeared to be higher than those with PI values in the range 50-69 (see Table 2). This was indicative of recent FMDV infection with possible active FMDV circulation in the field.

The sampled interface areas had a good number of buffalo and cattle herds, except for Mkomazi national park, which had a considerable number of buffalo and cattle herds. The number and size of buffalo and cattle herds could be contributing factors in the demonstrated variation in FMDV infection status (PI value variations). In addition these areas vary in terms of pasture and water availability, which may cause the movement of pastoralists and buffalo herds. However, the epidemiology of FMD in Tanzania remains complicated, as is the case in other sub-Saharan countries (Vosloo et al. 2002). The contributing factors include the large number of serotypes, the genetic and antigenic variation occurring in different regions, uncontrolled animal movement and the presence of multiple species of wildlife and domestic animals that can harbour the FMDV for variable time intervals.

\section{Acknowledgements}

This research study was conducted at the Tanzania Veterinary Laboratory Agency - Centre for Infectious Diseases and Biotechnology (TVLA-CIDB) laboratory with support from SACIDS, SADC/TADs, SUA and the Ministry of Livestock and Fisheries Development. We would like to thank BVI for their support in terms of technical laboratory skills and in particular Mr Gladson Joshua, laboratory technician. This work was supported by the Wellcome Trust Grant WT087546MA to the Southern African Centre for Infectious Diseases \& Surveillance (SACIDS).

TABLE 2: Grouped PI value for buffalo and cattle samples from interface areas.

\begin{tabular}{|c|c|c|c|c|c|c|c|}
\hline Location & Animal species & Samples tested & Positive samples & Samples with PI 50-69 & Samples with PI 70-100 & $\%$ for PI 50-69 & $\%$ for $\mathrm{PI} 70-100$ \\
\hline \multirow[t]{2}{*}{ Mikumi } & Buffalo & 30 & 28 & 7 & 21 & 25.00 & 75.00 \\
\hline & Cattle & 35 & 29 & 6 & 23 & 20.69 & 79.31 \\
\hline \multirow[t]{2}{*}{ Ruaha } & Buffalo & 31 & 29 & 1 & 28 & 3.45 & 96.55 \\
\hline & Cattle & 53 & 42 & 12 & 30 & 28.57 & 71.43 \\
\hline \multirow[t]{2}{*}{ Mkomazi } & Buffalo & 31 & 7 & 3 & 4 & 42.86 & 57.14 \\
\hline & Cattle & 60 & 35 & 5 & 30 & 14.29 & 85.71 \\
\hline \multirow[t]{2}{*}{ Katavi } & Buffalo & 29 & 29 & 3 & 26 & 10.34 & 89.66 \\
\hline & Cattle & 61 & 49 & 7 & 42 & 14.29 & 85.71 \\
\hline Total & - & 330 & 248 & 44 & 204 & 19.94 & 80.06 \\
\hline
\end{tabular}




\section{Competing interests}

The authors declare that they have no financial or personal relationship(s) that may have inappropriately influenced them in writing this article.

\section{Authors' contributions}

M.M. (Tanzania Veterinary Laboratory Agency) was the first author and participated in study development, field sample collection, laboratory analysis and manuscript writing. C.J.K. and P.W. (both Sokoine University of Agriculture) provided technical support in developing this study. R.S. and M.Y. (Tanzania Veterinary Laboratory Agency) participated in the laboratory analysis of the obtained samples. E.R. (Ministry of Livestock and Fisheries Development Tanzania) and M.M. (SADC TADS) participated in field sample collection. M.R. (Sokoine University of Agriculture) was the project leader.

\section{References}

Alexandersen, S., Zhang, Z. \& Donaldson, A., 2002, 'Aspects of the persistence of footand-mouth disease virus in animals - the carrier problem', Microbes and Infection 4, 1099-1110. http://dx.doi.org/10.1016/S1286-4579(02)01634-9

Brown, F., 2003, 'The history of research in foot and mouth disease', Virus Research 91, 3-7. http://dx.doi.org/10.1016/S0168-1702(02)00268-X

Donaldson, A.I., Kitching, R.P. \& Barnett, P.V., 1996, 'Foot and mouth disease', in OIE Standards Commission (eds.), Manual of Standards for Diagnostic Tests and Vaccines, pp. 47-56, Office International des Epizooties, Paris, France.
Frank, N.M., Chrisostom, A., Alexandersen, S., Willium, O., Okurut, A. \& Kristen, T., 2010, 'Seroepidemiological investigation of foot and mouth disease virus serotypes in cattle around Lake Mburo national park in South-Western Uganda', Journal of Veterinary Medicine and Animal Health 2(4), 46-54.

Lubroth, J. \& Brown, F., 1995, 'Identification of native foot and mouth disease virus non-structural protein $2 \mathrm{C}$ as a serological indicator to differentiate infected from vaccinated livestock', Research in Veterinary Science 59, 70-78. http://dx.doi. vaccinated livestock', Research in Vete
org/10.1016/0034-5288(95)90034-9

Mackay, D., Forsyth, M., Davies P., Berlinzani, A., Belsham G.J., Flint, M. et al., 1997, 'Differentiating infection from vaccination in foot-and-mouth disease using a panel of recombinant, non-structural proteins in ELISA', Vaccine 16, 446-459. http:// dx.doi.org/10.1016/S0264-410X(97)00227-2

Ministry of Livestock and Fisheries Development (MoLFD), 2010, 'Tanzania is rich in livestock resources in terms of number and variety', viewed 07 April 2013, from http://www.mifugo.go.tz/livestock_resources/

Nyamurunda, C., Melewas, J., Sendalo, D., Mtenga, L. \& Rwezaula, D., 2007, 'Sustaining livestock productivity in challenging tropical environments as a contribution towards achieving Millennium Development Goals', Proceedings of the 2nd Join Tanzania Veterinary Association and Tanzania Society of Animal Production, 29 November to 1 December.

Office International des Epizooties (OIE), 2009, 'Foot and mouth disease', viewed 14 April 2013, from http://www.oie.int/fileadmin/Home/eng/Health_standards/ April 2013, from http:///W
tahm/2.01.05_FMD.pdf.

Office International des Epizooties (OIE), 2010, 'Terrestrial animal health code: Article 8.5.48: Foot and mouth disease', viewed 17 March 2013, from http://web.oie.int/ eng/normes/mcode/en_chapitre_1.8.5.htm.

Rweyemamu, M. \& Loretu, K., 1972, 'Observation of foot and mouth disease in Tanzania', Bulletin of Epizootic Diseases of Africa 20, 101

Rweyemamu, M., Roeder, P., Mackay, D., Sumption, K., Brownlie, J., Leforban, Y. et al., 2008, 'Epidemiological patterns of foot and mouth disease worldwide', Transboundary and Emerging Disease 55(1), 57-72. http://dx.doi.org/10.1111/j.1865-1682.2007 01013.x

Sorensen, K., De Stricker, K., Dyrting, K., Grazioli, S. \& Haas, B., 2005, 'Differentiation of foot and mouth disease virus infected animals from expressed FMDV $3 A B C$ antigen and a $3 A B C$ monoclonal antibody', Archives of Virology 150, 805-814. http://dx.doi. org/10.1007/s00705-004-0455-z

Vosloo, W., Bastos, A., Sangare, O., Hargreaves, S. \& Thomson, G., 2002, 'Review of the status and control of foot and mouth disease in Sub-Saharan Africa', Revue Scientifique et Technique de l'Office International des Epizooties 21(3), 437-449. 